\title{
HUKUM PENGGUNAAN APLIKASI FACEAPP DALAM PERSPEKTIF HUKUM ISLAM
}

\author{
Muhammad Yusram \\ Sekolah Tinggi Islam dan Bahasa Arab (STIBA) Makassar \\ Email: yusrananshar@stiba.ac.id \\ Askar Patahuddin \\ Sekolah Tinggi Islam dan Bahasa Arab (STIBA) Makassar \\ Email: askarfatahuddin@stiba.ac.id \\ Ahmad Risal \\ Sekolah Tinggi Islam dan Bahasa Arab (STIBA) Makassar \\ Email: rizalalmaruky@gmail.com
}

Keywords :

ABSTRACT

FaceApp, Change, Creation, This study aims to determine the legal use of the FaceApp Law, Application application in terms of the Qur'an, sunnah, and opinions of the scholars, as well as its relation to the problem of changing God's creation. This study uses descriptive-qualitative with content analysis and library research technique. The results showed that: first, FaceApp is an application that can change face photos using technology in the form of neural networks that automatically produce very realistic facial transformations in photographs. The opinions of the scholars in the matter of changing God's creation are: 1) neutering humans and animals ;2) changing physical form; 3) make a tattoo on the body; 4) change the religion of God. Second, the legal use of the FaceApp application in an Islamic perspective by the scholars was divided into two: some scholars banned the use of the FaceApp application and others allowed it. Nevertheless, the majority of the scholars chose to forbid it, based on the evidence in the Qur'an and related hadith and the number of violations and harms posed by this application.

Kata kunci :

FaceApp, Mengubah, Ciptaan, Hukum, Aplikasi

\section{ABSTRAK}

Penelitian ini bertujuan untuk mengetahui hukum penggunaan aplikasi FaceApp ditinjau dari Al-Qur'an, sunah, dan pendapat para ulama, serta kaitannya dengan masalah mengubah ciptaan Allah. Penelitian ini menggunakan jenis deskriptif-kualitatif dengan teknik analisis konten dan riset kepustakaan (library research). Hasil penelitian menunjukkan bahwa: Pertama, FaceApp adalah aplikasi yang dapat mengubah foto wajah dengan menggunakan teknologi berupa jaringan saraf yang secara otomatis menghasilkan 

ulama dalam masalah mengubah ciptaan Allah melingkupi: 1) mengebiri manusia dan binatang; 2) mengubah bentuk fisik; 3) membuat tato di tubuh; 4) mengubah agama Allah. Kedua, hukum penggunaan aplikasi FaceApp dalam perspektif Islam oleh para ulama terbagi menjadi dua: sebagian ulama mengharamkan penggunaan aplikasi FaceApp dan sebagian lainnya membolehkannya. Namun demikian, mayoritas ulama memilih untuk mengharamkannya, berdasarkan dalil-dalil dalam Al-Qur'an dan hadis yang terkait serta banyaknya pelanggaran dan mudarat yang ditimbulkan oleh aplikasi ini.

\section{PENDAHULUAN}

Ada banyak hadis yang menyebutkan larangan menggambar makhluk bernyawa. Namun dengan berkembang pesatnya teknologi di tengah masyarakat, mulailah bermunculan beberapa alat canggih, di antaranya adalah kamera yang dapat mengambil gambar secara langsung, yaitu dengan memotretnya, sehingga manusia tidak perlu lagi menggambar dengan tangannya sendiri.

Mengenai hal tersebut, para ulama berbeda pendapat dalam menentukan hukum memotret gambar dengan kamera. Perbedaan pendapat ini muncul karena pada zaman Rasulullah saw. dan para sahabatnya belum ada alat yang bisa memotret gambar. Di dalam Al-Qur'an dan sunah pun belum disebutkan secara jelas tentang hukum menggunakan kamera. Sementara itu, perkembangan teknologi pun menghasilkan pembaharuan terhadap alat tersebut yang tidak hanya mampu mengambil dan memotret gambar atau objek yang diinginkan, tetapi juga mampu mengubah, mengedit atau merekayasa gambar atau objek yang telah dipotret dari bentuk aslinya melalui sebuah aplikasi atau software. Salah satu aplikasi pengedit gambar yang sempat viral adalah FaceApp. FaceApp adalah aplikasi yang dapat mengubah foto wajah menjadi lebih muda, lebih tua, atau mengubah gender. Sekilas, aplikasi ini terlihat menyenangkan sehingga banyak orang yang tertarik untuk menggunakannya. Salah satu fitur dalam aplikasi ini yang paling digemari banyak orang adalah mengedit dan mengubah wajah menjadi lebih tua. Sebagian dari mereka menggunakan aplikasi ini untuk lucu-lucuan saja, dan ada juga yang menggunakannya untuk mengetahui bentuk wajahnya ketika tua nanti.

Berangkat dari hal tersebut, timbul pertanyaan, sejauh mana dalil Al-Qur'an dan sunah menjelaskan makna mengubah ciptaan Allah jika dikaitkan dengan penggunaan aplikasi tersebut? Bagaimana hukum penggunaan aplikasi FaceApp melalui kamera dalam perspektif hukum Islam? Olehnya, penelitian ini bertujuan untuk mengetahui hukum penggunaan aplikasi FaceApp dalam perspektif hukum Islam. 
Penelitian ini menggunakan metode penelitian deskriptif-kualitatif dengan teknik analisis konten dan riset kepustakaan (library research). Penelitian kepustakaan merupakan upaya mengkaji literatur yang dijadikan sumber data kemudian membandingkan dengan hasil penelitian yang sudah ada dan terbaru. Tujuannya ialah untuk mendapatkan landasan teori mengenai masalah yang diteliti . ${ }^{1}$ Adapun teknik content analisys (analisis isi) merupakan metode penelitian yang digunakan untuk mengetahui simpulan dari sebuah manuskrip/teks dengan menggunakan pendekatan teologis normatif dan filosofis pada dua sumber data primer berikut ini yakni kitab Taḥn̄m al-Tașīr wa al-Radd 'alā Man Abāhahu karya Ḥamūd bin 'Abdillāh alTuwaijirī dan Aḥ kāmu al-Tașī̄r fi al-Syañ̄'ah al-Islāmiyyah̉̉ karya 'Abdurraḥmān bin 'Abdul Khāliq sebagai objek telaah kepustakaan.

\section{PEMBAHASAN}

\section{Analisis Dalil Tentang Mengubah Ciptaan Allah (تغيير خلق الله)}

Tagyir khalqillāh تغغير خلق الله) terdiri dari kata tagyīr (تغير) dan khalqullāh ـ غَيََّر (تغيير) adalah bentuk masdar dari fiil gayyara-yugayyiru (بُغِيِّر (خلق) yang artinya "mengubah". ${ }^{4}$ Sedangkan kata khalq bentuk masdar

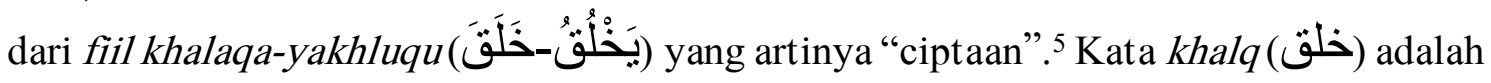
mudōāfdari kata khalqullāh (خلق الله) sehingga Khalqullāh (خلق الله) bermakna “ciptaan Allah". Adapun makna tagȳrr khalqillāh (تغيير خلق الله), jika berdasarkan kajian linguistik (bahasa), maka artinya adalah "mengubah ciptaan Allah".

Menurut al-Sa'dī dalam kitabnya, Tafsīr al-Sa’dî, tagȳir khalqillāh ( تغبير خلق الله meliputi pengubahan penciptaan yang bersifat lahiriyah dan batiniyah. ${ }^{6}$ Pendapat al-Sa'dī ini senada dengan pendapat Wahbah al-Zuhailī. Menurut beliau, pengubahan ciptaan Allah dalam fitrah keagamaan termasuk pengubahan ciptaan Allah yang dilarang agama, baik secara material maupun secara nilai. ${ }^{7}$

\footnotetext{
${ }^{1}$ Jonathan Sarwono, Metode Penelitian Kuantitatif \& Kualitatif(Yogyakarta: Graha Ilmu, 2006), h. 26 .

${ }^{2}$ Ḥamūd bin 'Abdillāh al-Tuwaijirī, Tahnī̄m al-Tașwīr wa al-Radd 'alā Man Abāhahu, 1409 $\mathrm{H} / 1988 \mathrm{M}$.

3،Abdurraḥmān bin ‘Abdul Khāliq. Aḥōmu al-Tașwīr fi al-Syañ̄'ah al-Islāmiyyah, 1415 H/1994 M.

${ }^{4}$ Ahmad Warson Munawir, Kamus al-Munawwir: Arab-Indonesia (Yogyakarta: Pustaka Progresif, 2002), h. 1025.

${ }^{5}$ Ahmad Warson Munawir, Kamus al-Munawwir: Arab-Indonesia, h. 363.

6،Abdurraḥmān bin Nāșir bin 'Abdullāh al-Sa'dī, Taisīi al-Kañ̄m al-Rahmōnn fi Tafsīr Kalām alMannān, Jilid 1 (Cet. I; Beirut: Mu’assasah al-Risālah, 1420 H/2000 M), h. 203.

${ }^{7}$ Wahbah al-Zuhailī, al-Tafsìrul al-Waj̄iz, (Cet. II; Damaskus: Dār al-Fikr, 1416 H/1996 M), h. 98.
} 
Sedangkan menurut Imam al-Ṭabarī dalam tafsirnya, Jamī' al-Bayān fi Ta'wīl alQur'ān, makna tagȳir khalqillāh (تغيير خلق الله) adalah mengubah agama Allah, sehingga pengertian ini mencakup semua hal yang dilarang oleh Allah. Allah swt. berfirman dalam Q.S. al-Nisā'/4:118-119:

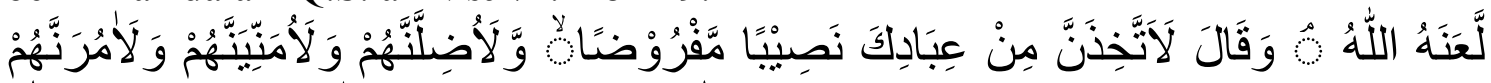

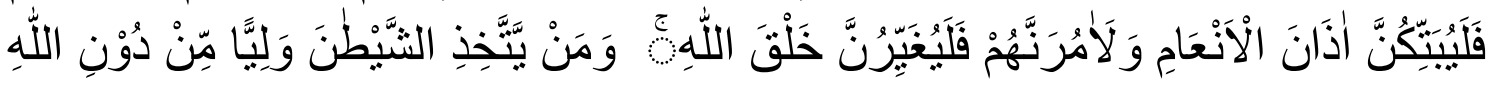

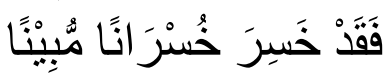

Terjemahnya:

yang dilaknati Allah, dan (setan) itu mengatakan, "Aku pasti akan mengambil bagian tertentu dari hamba-hamba-Mu, dan pasti kusesatkan mereka, dan akan kubangkitkan angan-angan kosong pada mereka dan akan kusuruh mereka memotong telinga-telinga binatang ternak, (lalu mereka benar-benar memotongnya), dan akan aku suruh mereka mengubah ciptaan Allah, (lalu mereka benar-benar mengubahnya)." Barangsiapa menjadikan setan sebagai pelindung selain Allah, maka sungguh, dia menderita kerugian yang nyata. ${ }^{8}$

Ibnu Jarīr meriwayatkan:

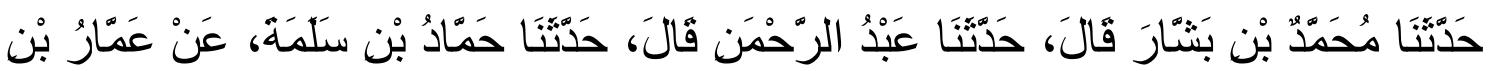

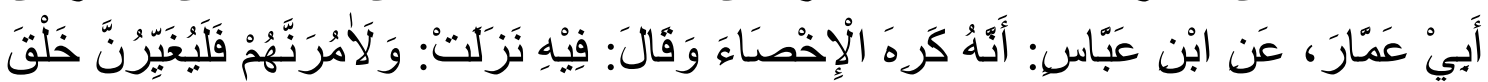
9 اللإنهن

Artinya:

Muhammad bin Basysyār berkata: Abdurraḥmān berkata: "Hammād bin Salamah telah menyebutkan dari Ammār bin Abu Ammār dari Abdullāh bin Abbās: "Bahwa dia tidak suka pengebirian, (Abdullāh bin Abbās) berkata: "Tentang inilah turunlah Q.S. al-Nisā'/4: 119:

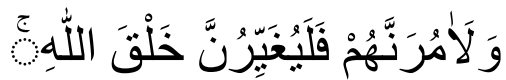

Terjemahnya:

(Setan berkata), “...Dan akan aku suruh mereka mengubah ciptaan Allah, (lalu mereka benar-benar mengubahnya)" ${ }^{10}$

Berikut ini adalah penafsiran Q.S. al-Nisā'/4: 119 dari beberapa mufasir, di antaranya:

${ }^{8}$ Kementrian Agama RI, Al-Qur'an dan Terjemahnya (Jakarta: Almahira, 2017), h. 97.

${ }^{9}$ Abu Ja'far Muhammad bin Jarīr al-Tabarī, Jamī' al-Bayān fi Ta'wīl al-Qur'ān, Jilid 9 (Beirut: Mu'assasah al-Risālah, 1420 H/2000 M), h. 215.

${ }^{10}$ Kementrian Agama RI, Al-Qur'an dan Terjemahnya, h. 97. 
a. Tafsir al-Qurțubī

Penafsiran Q.S. al-Nisā'/4: 119 yang berkaitan dengan mengubah ciptaan Allah menurut al-Qurțubī (w. 671 H/1273 M) mengacu kepada pengubahan bentuk fisik manusia dan binatang serta pengubahan terhadap fitrah keagamaan. Hal itu terjadi atas dasar godaan setan melalui janji dan rayuannya, padahal setan tersebut tidak menjanjikan sesuatu melainkan hanya tipuan belaka.

Mengenai makna mengubah ciptaan Allah pada fitrah keagamaan, al-Qurțubī mengemukakan tentang ciptaan Allah (makhluk-Nya) yang disalahgunakan, yang seharusnya binatang diciptakan sebagai tunggangan dan dagingnya sebagai makanan, serta menciptakan matahari, bebatuan dan berbagai sesuatu untuk dijadikan sebagai iktibar dan didayagunakan kemanfaatannya. Akan tetapi semuanya itu diubah menjadi ilah yang disembah dan hal itu merupakan perbuatan-perbuatan yang menjadikan sekutu bagi Allah dan menyalahi perintah untuk bertauhid, yang kesemuanya itu mengajak kepada neraka dan akan menghancurkan akidah. ${ }^{11}$

Walaupun al-Qurțubī banyak mengurai penafsirannya, tetapi beliau tidak begitu jelas menyebutkan hukum pengubahan tersebut. Akan tetapi agaknya dapat dilihat dari penafsirannya dan pendapat-pendapat serta hadis-hadis yang beliau kutip lebih cenderung kepada tidak membolehkan (melarang) pengubahan tersebut.

Al-Qurțubī mengutip hadis yang diriwayatkan oleh Ibnu Mas'ūd bahwa Rasulullah saw. bersabda: ${ }^{12}$

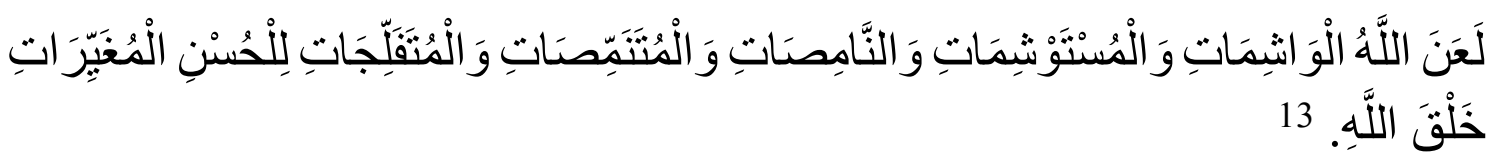

Artinya:

Allah melaknat para wanita pembuat tato dan yang meminta dibuatkan tato, para wanita yang mencukur alis mereka dan para wanita yang meminta untuk dicukur alis mereka, dan para wanita yang mengikir gigi mereka, dengan tujuan mempercantik diri mereka, serta mengubah ciptaan Allah Ta'ala.

Menurut al-Qurțubī, hadis yang diriwayatkan oleh Ibnu Mas'ūd merupakan hadis sahih. Kemudian al-Qurțubī juga mengutip pendapat, yaitu pendapat Abū Ja'far al-

\footnotetext{
${ }^{11}$ Abū 'Abdullāh Muhammad bin Ahmad bin Abu Bakr al-Anșarī al-Qurțubī, al-Jāmi' li Ahkām al-Qur'ān, Jilid 5 (Cet. II; Kairo: Dār al-Kutub al-Mișriyyah, 1384 H/1964 M), h. 389.

${ }^{12}$ Abū 'Abdullāh Muhammad bin Ahmad bin Abu Bakr al-Anșarī al-Qurțubī, al-Jāmi' li Ahkām al-Qur'ān, Jilid 5, h. 392.

${ }^{13}$ Abū 'Abdillāh Muhammad bin Ismā‘̄il bin Ibrāhīm bin al-Mugīrah bin Bardizbah al-Ju'fī alBukhārī, Șaḥị̣ al-Bukhān̄̄, Jilid 6 (Cet. I; Beirut: Dār Ṭūq al-Najāh, 1422 H/2002 M), h. 147 dan Abū alḤusain Muslim bin al-Ḥajjāj al-Qusyairī al-Naisābūrī, Șạ̣ ị̣ Muslim, Jilid 3 (Beirut: Dār Ihyā'u al-Turās al-'Arabī, 1374 H/1954 M), h. 1678.
} 
Țabarī bahwa hadis Ibnu Mas'ūd tersebut merupakan dalil pelarangan mengubah ciptaan Allah baik dengan menambah-nambahi ataupun menguranginya dengan tujuan berpenampilan lebih baik dihadapan suami ataupun orang lain. Apakah itu dengan merenggangkan giginya ataupun dengan bentuk pengubahan lainnya, atau juga mencukur bulu (wajah atau alis) dan sebagainya. ${ }^{14}$

Al-Qurțubī menyebutkan pengecualian terhadap hukum pengubahan yang dibolehkan yaitu pengubahan yang dilakukan karena darurat atau kalau tidak diubah, maka hal itu akan menimbulkan mudarat atau rasa sakit yang menyiksa. Selain itu, AlQurțubī juga membolehkannya jika maksud mengubah ciptaan Allah adalah mengebiri binatang, sebagaimana perkataannya:

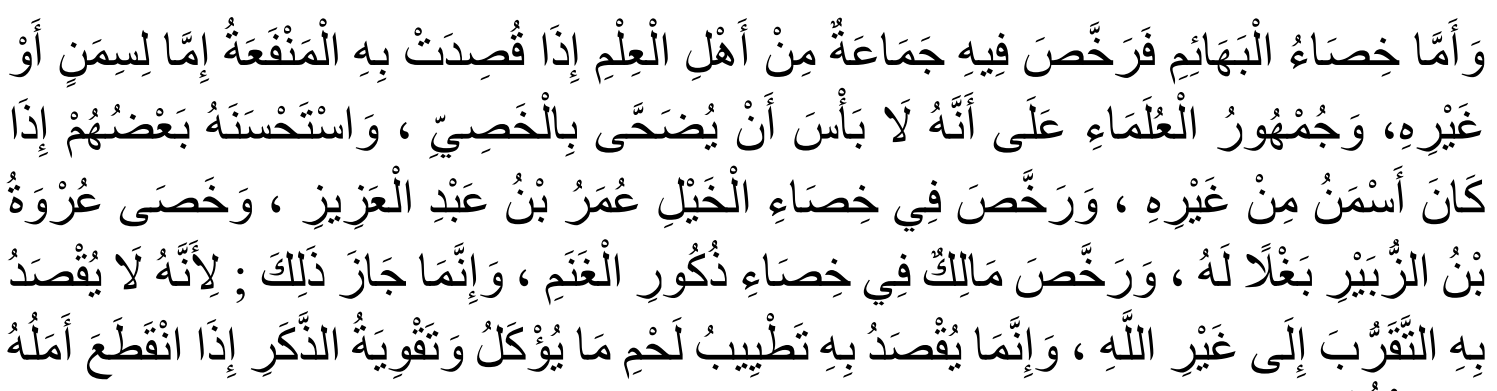
15

Artinya:

Adapun mengebiri binatang ternak, sebagian ulama membolehkannya, selama itu membawa manfaat, seperti bertambah gemuk atau manfaat lainnya. Mayoritas ulama juga membolehkan seseorang berkurban dengan hewan yang dikebiri, bahkan sebagian dari mereka mengatakan hal itu baik jika memang menjadi lebih gemuk dari hewan lainnya yang tidak dikebiri. Umar bin Abdul Aziz juga membolehkan pengebirian kuda, Urwah bin Zubair pernah mengebiri bagalnya, Imam Malik membolehkan pengebirian kambing jantan. Semua itu dibolehkan karena tujuan dari pengebirian hewan itu bukanlah untuk dipersembahkan kepada kepada berhala yang disembah, dan bukan pula kepada rabb yang diesakan. Tetapi pengebirian itu dimaksudkan agar daging yang akan dimakan itu lebih baik, dan pengebirian itu sendiri bisa menguatkan hewan jantan, karena dia tidak pernah menghampiri hewan betina.

b. Tafsir Ibnu Kasīir

Penafsiran Q.S. al-Nisā'/4: 119 yang berkaitan dengan mengubah ciptaan Allah menurut Ibnu Kasiīr (w. 774 H/1372 M) adalah sebagai berikut.

\footnotetext{
${ }^{14}$ Abū 'Abdullāh Muhammad bin Ahmad bin Abu Bakr al-Anșarī al-Qurțubī, al-Jāmi' li Ahkām al-Qur'ān, Jilid 5, h. 393.

${ }^{15}$ Abū 'Abdullāh Muhammad bin Ahmad bin Abu Bakr al-Anșarī al-Qurțubī, al-Jāmi' li Ahkām al-Qur'ān, Jilid 5 (Cet. II; Kairo: Dār al-Kutub al-Mișriyyah, 1384 H/1964 M), h. 390.
} 
Allah swt. berfirman:

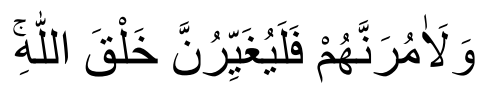

Terjemahnya:

Dan akan aku suruh mereka mengubah ciptaan Allah, (lalu mereka benar-benar mengubahnya. ${ }^{16}$

Ibnu 'Abbās mengatakan, yang dimaksud dengan mengubah ciptaan Allah dalam ayat ini ialah mengebiri binatang ternak. Hal yang sama diriwayatkan dari Ibnu Umar, Anas, Sa'̄̄d bin al-Musayyab, 'Ikrimah, Abū Iyād, Qatādah, Abū Sālih, Al-Saurī. Hal ini telah dilarang oleh hadis yang menceritakan hal tersebut. ${ }^{17}$

Al-Hasan Ibnu Abu al-Hasan Al-Basri mengatakan, yang dimaksud ialah menato. Allah swt. melaknat orang yang berbuat demikian, sebagaimana sabda Rasulullah saw.:
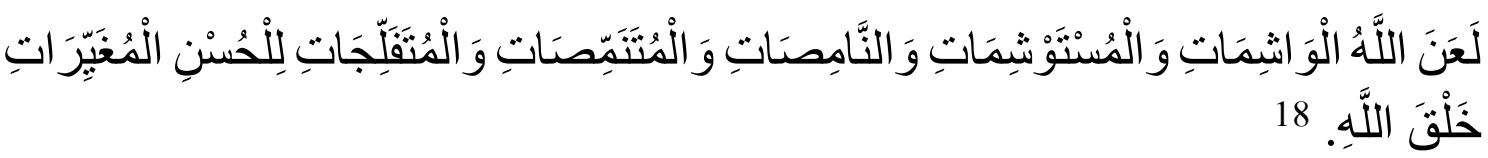

Artinya:

Allah melaknat para wanita pembuat tato dan yang meminta dibuatkan tato, para wanita yang mencukur alis mereka dan para wanita yang meminta untuk dicukur alis mereka, dan para wanita yang mengikir gigi mereka, dengan tujuan mempercantik diri mereka, serta mengubah ciptaan Allah Ta'ala.

Kemudian Ibnu Mas'ūd mengatakan pula, "Camkanlah, aku melaknat orang yang dilaknat oleh Rasulullah saw. Hal ini terdapat di dalam Q.S. al-Hasyr/59: 7:

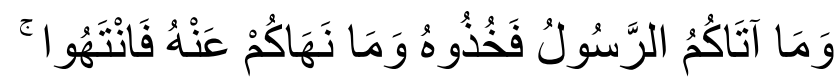

Terjemahnya:

Apa yang diberikan Rasul kepadamu, maka terimalah. Dan apa yang dilarangnya bagimu, maka tinggalkanlah. ${ }^{19}$

Maksud dari khalqallāh dalam ayat ini menurut Ibnu 'Abbās, Mujāhid, 'Ikrimah, Ibrāhim al-Nakhā'ī, al-Hasan, Qatādah, al-Hakam, al-Suddī, al-Dahhak, dan Ata alKhurasanī adalah agama Allah swt. ${ }^{20}$ Ayat ini berdasarkan tafsir tersebut semakna dengan firman Allah swt. dalam Q.S. al-Rūm/30: 30:

\footnotetext{
${ }^{16}$ Kementrian Agama RI, Al-Qur'an dan Terjemahnya, h. 97.

${ }^{17}$ Abū al-Fidā' Ismāīîl bin 'Umar bin Kas̀īr, Tafsìr al-Qur'ān al- 'Aẓīm, Jilid 2 (Cet. I; Beirut: Dār al-Kutub al-'Ilmiyyah, 1419 H/1999 M), h. 367.

${ }^{18}$ Abū 'Abdillāh Muhammad bin Ismā'īl bin Ibrāhīm bin al-Mugīrah bin Bardizbah al-Ju'fī alBukhārī, Șạ̣ị̣ al-Bukhān̄̄, Jilid 6, h. 147 dan Abū al-Ḥusain Muslim bin al-Ḥajjāj al-Qusyairī al-Naisābūrī, Șậh Muslim, Jilid 3, h. 1678.

${ }^{19}$ Kementrian Agama RI, Al-Qur'an dan Terjemahnya, h. 546.

${ }^{20}$ Abū al-Fidā' Ismāīl bin 'Umar bin Kas̀īr, Tafsīr al-Qur'ān al- 'Aẓīm, Jilid 2, h. 367.
} 


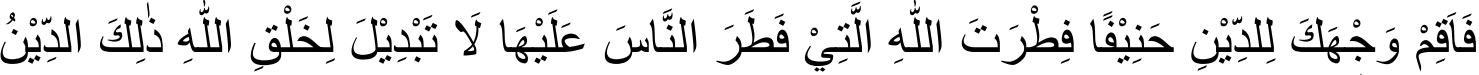

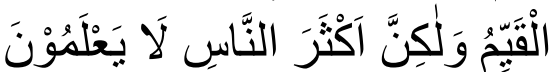

Terjemahnya:

Maka hadapkanlah wajahmu dengan lurus kepada agama (Islam); (sesuai) fitrah Allah disebabkan Dia telah menciptakan manusia menurut (fitrah) itu. Tidak ada perubahan pada ciptaan Allah. (Itulah) agama yang lurus, tetapi kebanyakan manusia tidak mengetahui. ${ }^{21}$

Menurut penafsiran orang yang menjadikan masdar sebagai kata perintah, artinya adalah 'janganlah kalian mengganti fitrah Allah, dan serulah manusia untuk kembali kepada fitrah mereka', seperti yang disebutkan di dalam sebuah hadis bahwa Rasulullah saw. bersabda:

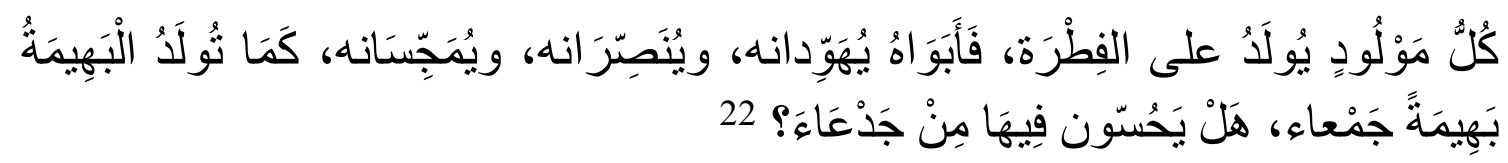

Artinya:

Setiap anak dilahirkan atas fitrah, maka hanya kedua orang tuanyalah yang menjadikannya seorang Yahudi, atau seorang Nasrani, atau seorang Majusi. Sebagaimana binatang ternak melahirkan binatang ternak yang utuh, maka apakah kalian menjumpai padanya anggota tubuhnya yang tidak lengkap?

Disebutkan dari 'Iyaḍ bin Himār, Rasulullah saw. bersabda, Allah swt. berfirman:

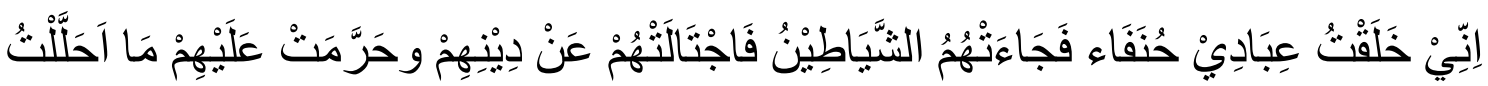

Artinya:

Sesungguhnya Aku telah menciptakan hamba-hamba-Ku cenderung kepada agama-Ku, maka datanglah setan kepada mereka, lalu setan itu memalingkan mereka dari agamanya dan ia mengharamkan apa yang telah Aku halalkan bagi mereka.

c. Maḥāsin al-Ta’wīl

Jamāluddīn al-Qāsimī (w. 1332 H/1914 M), penulis Mahāsin al-Ta’w̄l menafsirkan "ciptaan Allah" dengan mengutip sejumlah tafsir. Menurutnya, "ciptaan

${ }^{21}$ Kementrian Agama RI, Al-Qur'an dan Terjemahnya, h. 407.

${ }^{22} \mathrm{Abū}$ 'Abdillāh Muhammad bin Ismā‘īl bin Ibrāhīm bin al-Mugīrah bin Bardizbah al-Ju‘fĩ alBukhārī, Șahịh al-Bukhārī̄, Jilid 2, h. 100 dan Abū al-Husain Muslim bin al-Hajjāj al-Qusyairī al-Naisābūrī, Șahịh Muslim, Jilid 4, h. 2047.

${ }^{23}$ Abū al-Ḥusain Muslim bin al-Ḥajjāj al-Qusyairī al-Naisābūrī, Șahị Muslim, Jilid 4, h. 2197. 
Allah" yang dimaksud adalah agama Allah sebagaimana penafsiran sahabat Ibnu 'Abbās dan banyak ahli tafsir. Pandangan ini didukung oleh Q.S. al-Rūm/30 ayat 30 yang menyebut agama-Nya sebagai fitrah manusia dan ciptaan Allah dan hadis riwayat Bukhārī serta Muslim bahwa setiap manusia terlahir dalam kondisi fitrah, yaitu Islam, tetapi kemudian diubah oleh orang tua dan lingkungannya menjadi agama lain. Beliau mengatakan:

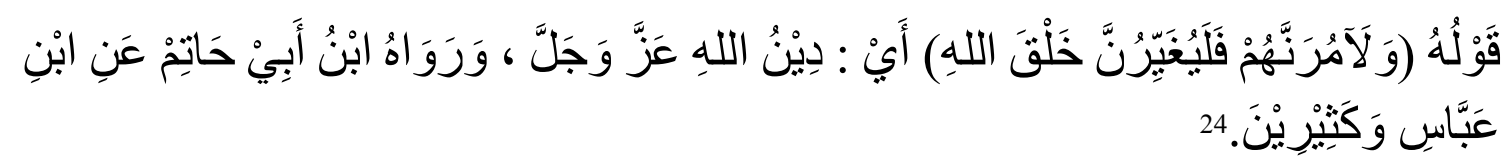

Artinya:

Firman Allah: "Aku (setan) akan memerintahkan mereka (manusia) untuk mengubah ciptaan Allah”, maksudnya agama Allah sebagaimana riwayat Ibnu Abī Ḥātim dan Ibnu 'Abbās dan banyak ahli tafsir.

Jamāluddīn al-Qāsimī juga mengutip pandangan ulama tafsir lain yang menyebutkan bahwa pengubahan ciptaan Allah atau fitrah Allah untuk manusia itu berupa pengubahan organ fisik manusia dan juga hewan yaitu praktik kebiri.

d. Tafsir al-Sa'dī

Al-Sa'dī (w. 1376 H/1956 M) menafsirkan Q.S. al-Nisā'/4: 119 yang berkaitan dengan mengubah ciptaan Allah dalam kitabnya, Tafsīr al-Sa'dī:

Ayat ini menyebutkan bahwa setan telah bersumpah kepada Allah untuk menggoda manusia agar mereka mengubah ciptaan Allah swt., sebagaimana firman Allah swt.:

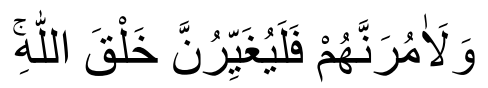

Terjemahnya:

Dan akan aku suruh mereka mengubah ciptaan Allah, (lalu mereka benar-benar mengubahnya. ${ }^{25}$

Hal ini meliputi pengubahan penciptaan lahiriyah. Tujuan setan memperdaya manusia adalah agar mereka tidak puas dengan ciptaan-Nya serta berkeyakinan bahwa yang mereka lakukan dengan tangan-tangan mereka itu lebih indah dari penciptaan Allah dan mereka tidak rida dengan aturan-Nya.

Hal itu juga mencakup perubahan penciptaan yang bersifat batin. Sesungguhnya Allah menciptakan makhluk dalam keadaan suci dan bernaluri untuk menerima

\footnotetext{
${ }^{24}$ Jamāluddīn al-Qāsimī, Mạ̣āsin al-Ta’w̄il, Jilid 5 (Cet. I; Damaskus: Dār al-Fikr, 1416 H/1996 M), h. 1568.

${ }^{25}$ Kementrian Agama RI, Al-Qur'an dan Terjemahnya, h. 97.
} 
kebenaran dan mendahulukannya hingga hadirlah setan kepada mereka lalu menggoda mereka untuk mengubah penciptaan yang indah itu. ${ }^{26}$

e. Al-Tafsīrul al-Wajīz

Menurut Wahbah al-Zuhailī (w. 1436 H/2015 M), pengubahan ciptaan Allah yang dilarang agama berupa organ fisik manusia sesuai fitrahnya dan nilai-nilai kebaikan, sebagaimana perkataannya:

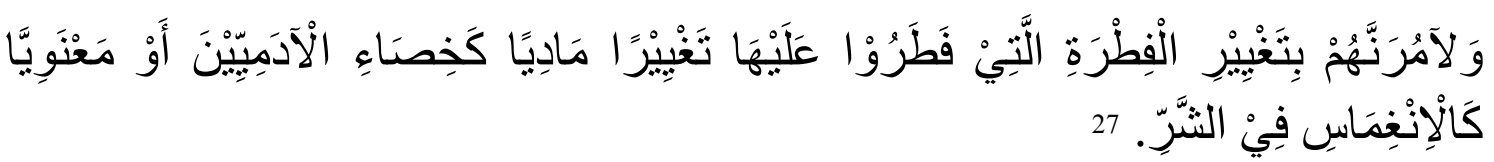

Artinya:

Kami (setan) akan memerintahkan mereka (manusia) untuk mengubah fitrah yang telah ditetapkan untuk mereka, baik secara material, yaitu mengebiri manusia maupun secara nilai, yaitu tenggelam dalam kejahatan.

Sebagaimana diterangkan pada ayat tersebut bahwa setan akan membisikan kepada manusia agar mereka mengubah ciptaan Allah, dan manusia tersebut benar-benar akan mengubahnya. Namun, para ulama masih berbeda pendapat di dalam memahami maksud dari ayat di atas. ${ }^{28}$

Adapun pendapat para ulama tentang makna tagyīr khalqillāh (تغبير خلق الله) dalam Q.S. al-Nisā'/4: 119 adalah sebagai berikut:

Pendapat pertama: maksud dari mengubah ciptaan Allah adalah mengebiri manusia dan binatang. Pendapat ini dikemukakan oleh Jamāluddīn al-Qāsimī dalam kitabnya, Maḥ̄ sin al-Ta'wīl. ${ }^{29}$ Beliau mengutip pandangan ulama tafsir lain yang menyebutkan bahwa pengubahan ciptaan Allah atau fitrah Allah untuk manusia itu berupa pengubahan organ fisik manusia dan juga binatang, yaitu praktik kebiri.

Untuk hukum mengebiri manusia, para ulama sudah sepakat akan keharamannya. Sebagaimana dinyatakan oleh Imam Abū 'Umar bin Abdil Barr:

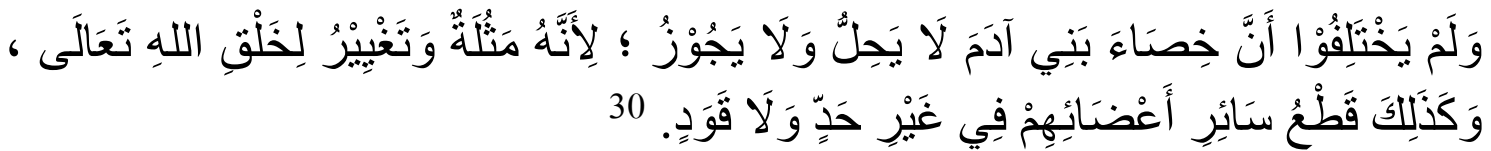

Artinya:

26، Abdurraḥmān bin Nāṣir bin 'Abdullāh al-Sa'dī, Taisīr al-Kan̄m al-Rahmōnn fị Tafsīr Kalām alMannān, Jilid 1, h. 203.

${ }^{27}$ Wahbah al-Zuhailī, al-Tafsīrul al-Waj̄z, h. 98.

${ }^{28} \mathrm{Abu}$ Ja'far Muhammad bin Jarīr al-Ṭabarī, Jamī’ al-Bayān fi Ta’wīl al-Qur'ān, Jilid 9, h. 215.

${ }^{29}$ Jamāluddīn al-Qāsimī, Mahāāsin al-Ta’wīl, Jilid 5, h. 1568.

${ }^{30} \mathrm{Abū}$ 'Umar Yūsuf bin Abdillah bin Muhammad bin Abdil Barr bin ‘Āṣim al-Namarī al-Qurțubī, al-Istiž kār $r$ Jilid 8 (Cet. I; Beirut: Dār al-Kutub al-'Ilmiyyah, 1421 H/2000 M), h. 433. 
Para ulama tidak berselisih pendapat bahwa mengebiri manusia tidak halal dan tidak boleh, karena merupakan bentuk penyiksaan dan mengubah ciptaan Allah. Begitu juga tidak boleh memotong anggota badannya yang lain, jika itu bukan karena hukuman had atau qisas.

Pendapat ini diperkuat oleh Wahbah al-Zuhailī. Menurutnya, pengubahan organ fisik manusia berupa praktik kebiri untuk manusia termasuk pengubahan ciptaan Allah yang dilarang agama, sebagaimana perkataannya:

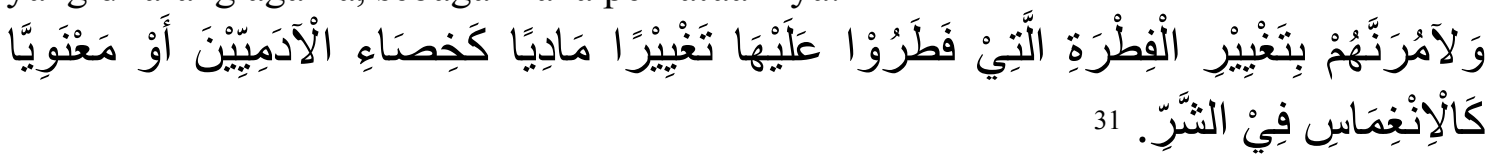

Artinya:

Kami (setan) akan memerintahkan mereka (manusia) untuk mengubah fitrah yang telah ditetapkan untuk mereka, baik secara material, yaitu mengebiri manusia maupun secara nilai, yaitu tenggelam dalam kejahatan.

Akan tetapi, untuk mengebiri binatang para ulama masih berbeda pendapat di dalam menentukan status hukumnya.

Al-Qurțubī membolehkan seseorang mengebiri binatang selama itu membawa manfaat, seperti bertambah gemuk atau manfaat lainnya, sebagaimana perkataannya:

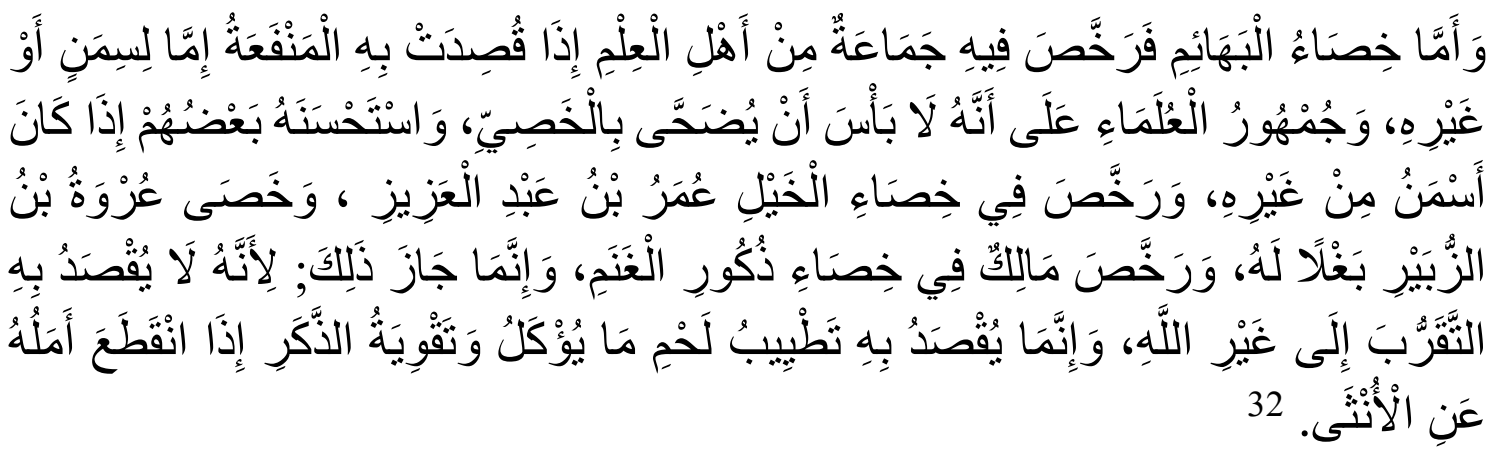

Artinya:

Adapun mengebiri binatang ternak, sebagian ulama membolehkannya, selama itu membawa manfaat, seperti bertambah gemuk atau manfaat lainnya. Mayoritas ulama juga membolehkan seseorang berkurban dengan hewan yang dikebiri, bahkan sebagian dari mereka mengatakan hal itu baik jika memang menjadi lebih gemuk dari hewan lainnya yang tidak dikebiri. Umar bin Abdul Aziz juga membolehkan pengebirian kuda, 'Urwah bin Zubair pernah mengebiri bighalnya, Imam Malik membolehkan pengebirian kambing jantan. Semua itu dibolehkan karena tujuan dari pengebirian hewan itu bukanlah untuk

\footnotetext{
${ }^{31}$ Wahbah al-Zuhailī, al-Tafsīrul al-Wajīz, h. 98.

${ }^{32}$ Abū 'Abdullāh Muhammad bin Ahmad bin Abu Bakr al-Anșarī al-Qurțubī, al-Jāmi’ li Ahkām al-Qur'ān, Jilid 5, h. 390.
} 
dipersembahkan kepada kepada berhala yang disembah, dan bukan pula kepada rabb yang diesakan. Tetapi pengebirian itu dimaksudkan agar daging yang akan dimakan itu lebih baik, dan pengebirian itu sendiri bisa menguatkan hewan jantan, karena dia tidak pernah menghampiri hewan betina.

Pendapat al-Qurțubī ini didukung oleh pendapat Ibnu 'Abbās ra. Menurut beliau, yang dimaksud dengan mengubah ciptaan Allah dalam Q.S. al-Nisā'/4: 119 adalah mengebiri binatang ternak.

Sebagaimana pendapat al-Qurțubī yang membolehkan mengebiri binatang ternak, maka hal tersebut didasarkan pada firman Allah swt. dalam Q.S. al-Hajj/22: 32:

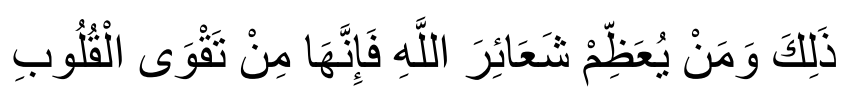

Terjemahnya:

Demikianlah (perintah Allah) dan barangsiapa mengagungkan syiar-syiar Allah, maka sesungguhnya itu timbul dari ketakwaan hati. ${ }^{33}$

Ketika menafsirkan ayat di atas, Ibnu 'Abbās ra. berkata:

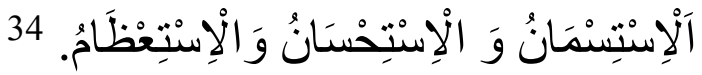

Artinya:

Yaitu menggemukan hewan kurban, memperindah dan membesarkannya.

Dengan dasar inilah sebagian ulama termasuk al-Qurțubī membolehkan seseorang berkurban dengan binatang ternak yang dikebiri, bahkan hal itu dianjurkan jika dia lebih gemuk dari pada yang lainnya. Walaupun demikian, gemuk secara alami dengan makan daun-daunan dan rerumputan juah lebih baik dari pada gemuk akibat dikebiri ataupun disuntik.

Pendapat kedua: maksud dari mengubah ciptaan Allah adalah mengubah bentuk fisik.

Pendapat ini dikemukakan oleh al-Qurțubī. Menurut beliau, penafsiran Q.S. alNisā'/4: 119 yang berkaitan dengan mengubah ciptaan Allah mengacu kepada pengubahan bentuk fisik manusia dan binatang. Mengenai hal tersebut, beliau lebih cenderung kepada tidak membolehkan (melarang) pengubahan tersebut.

Al-Qurțubī mengutip hadis yang diriwayatkan oleh Ibnu Mas'ūd bahwa Rasulullah saw. bersabda:

\footnotetext{
${ }^{33}$ Kementrian Agama RI, Al-Qur'an dan Terjemahnya, h. 336.

${ }^{34}$ Abū al-Fidā' Ismāīi bin 'Umar bin Kasīir, Tafsìr al-Qur'ān al- 'Aẓīm, Jilid 5, h. 370.
} 


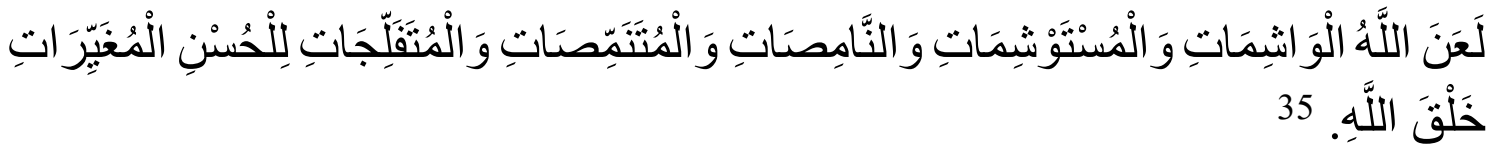

Artinya:

Allah melaknat para wanita pembuat tato dan yang meminta dibuatkan tato, para wanita yang mencukur alis mereka dan para wanita yang meminta untuk dicukur alis mereka, dan para wanita yang mengikir gigi mereka, dengan tujuan mempercantik diri mereka, serta mengubah ciptaan Allah Ta'ala.

Menurut al-Qurțubī, hadis yang diriwayatkan oleh Ibnu Mas'ūd ini merupakan hadis sahih. Kemudian al-Qurțubī juga mengutip pendapat, yaitu pendapat Abū Ja'far al-Ṭabarī bahwa hadis Ibnu Mas'ūd tersebut merupakan dalil pelarangan mengubah ciptaan Allah baik dengan menambah-nambahi ataupun menguranginya dengan tujuan berpenampilan lebih baik dihadapan suami ataupun orang lain. Apakah itu dengan merenggangkan giginya ataupun dengan bentuk pengubahan lainnya, atau juga mencukur bulu (wajah atau alis) dan sebagainya. ${ }^{36}$

Pendapat ini didukung oleh al-Sa'dī dalam kitabnya, Tafs̄ir al-Sa'dí. ${ }^{37}$ Menurutnya, hal tersebut meliputi pengubahan bentuk fisik. Dalam ayat ini disebutkan bahwa berusaha untuk memperdaya manusia agar mereka mengubah ciptaan Allah dengan cara mengubah bentuk fisik mereka. Tujuan setan memperdaya manusia adalah agar mereka tidak puas dengan ciptaan-Nya serta berkeyakinan bahwa yang mereka lakukan dengan tangan-tangan mereka itu lebih indah dari penciptaan Allah dan mereka tidak rida dengan aturan-Nya.

Namun demikian, al-Qurțubī menyebutkan pengecualian terhadap hukum pengubahan bentuk fisik yang dibolehkan, yaitu pengubahan yang dilakukan karena darurat atau kalau tidak diubah, maka hal itu akan menimbulkan mudarat atau rasa sakit yang menyiksa.

Pendapat ketiga: maksud dari mengubah ciptaan Allah adalah membuat tato di tubuh.

Tidak ada perselisihan di kalangan para ulama tentang keharaman membuat tato dalam tubuh. Hal ini berdasarkan hadis yang diriwayatkan oleh Ibnu Mas'ūd bahwa Rasulullah saw. bersabda:

\footnotetext{
${ }^{35}$ Abū 'Abdillāh Muhammad bin Ismā'̄il bin Ibrāhīm bin al-Mugīrah bin Bardizbah al-Ju'fī alBukhārī, Șạ̣ị̣ al-Bukhārī, Jilid 6, h. 147 dan Abū al-Ḥusain Muslim bin al-Ḥajjāj al-Qusyairī al-Naisābūrī, Șahị Muslim, Jilid 3, h. 1678.

${ }^{36}$ Abū 'Abdullāh Muhammad bin Ahmad bin Abu Bakr al-Anșarī al-Qurțubī, al-Jāmi' li Ahkām al-Qur'ān, Jilid 5, h. 393.

37، Abdurraḥmān bin Nāṣir bin 'Abdullāh al-Sa' dī, Taisīr al-Kan̄m al-Raḥmān fi Tafsìr Kalām alMannān, Jilid 1, h. 203.
} 


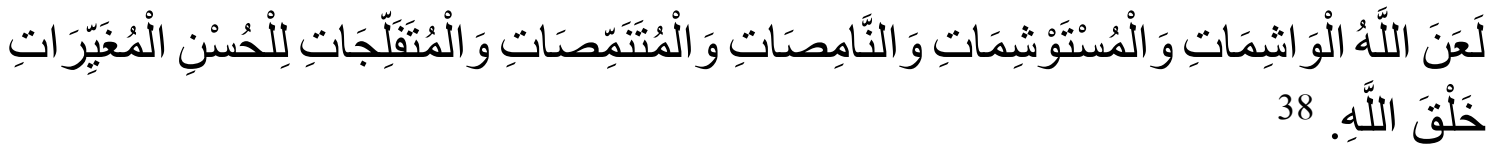

Artinya:

Allah melaknat para wanita pembuat tato dan yang meminta dibuatkan tato, para wanita yang mencukur alis mereka dan para wanita yang meminta untuk dicukur alis mereka, dan para wanita yang mengikir gigi mereka, dengan tujuan mempercantik diri mereka, serta mengubah ciptaan Allah Ta'ala.

Adapun maksud wasym dalam hadis ini adalah menusukkan jarum atau sejenisnya ke dalam kulit hingga berdarah, lalu mengisinya dengan celak atau sejenisnya sehingga menimbulkan warna berbeda pada kulit. Wasym adalah salah satu larangan agama, bahkan merupakan dosa besar, karena pelakunya dilaknat. Laknat artinya doa agar dijauhkan dari rahmat Allah swt. Para ulama menjelaskan bahwa wasym mengandung unsur mengubah ciptaan Allah swt. ${ }^{39}$

Pendapat ini didukung oleh Imam al-Sa'dī. Menurut beliau, perubahan yang dimaksud adalah perubahan yang bersifat lahiriyah, yaitu dengan tato, meruncingkan atau menajamkan gigi, mencabut alis, dan memberi celah pada gigi demi kecantikan dan semacamnya dari perkara-perkara yang menjadi sasaran setan demi memperdaya manusia, sehingga mereka mengubah ciptaan Allah. Tujuan setan memperdaya manusia adalah agar mereka tidak puas dengan ciptaan-Nya serta berkeyakinan bahwa yang mereka lakukan dengan tangan-tangan mereka itu lebih indah dari penciptaan Allah, mereka tidak rida dengan aturan-Nya. ${ }^{40}$

Al-Hasan Ibnu Abu al-Hasan Al-Basri mengatakan, yang dimaksud dengan mengubah ciptaan Allah dalam Q.S. al-Nisā'/4: 119 adalah menato binatang ternak.

Pendapat keempat: maksud mengubah ciptaan Allah adalah mengubah agama Allah. Pendapat ini dipilih oleh Imam al-Ṭabarī dalam tafsirnya, Jamī' al-Bayān fi Ta'wīl al-Qur'ān.

Beliau mengatakan: Jika memang arti mengubah ciptaan Allah adalah demikian (yaitu mengubah agama Allah), berarti semua yang dilarang oleh Allah masuk dalam kategori ini, termasuk di dalamnya larangan mengebiri sesuatu yang memang dilarang

${ }^{38}$ Abū 'Abdillāh Muhammad bin Ismā‘īl bin Ibrāhīm bin al-Mugīrah bin Bardizbah al-Ju'fī alBukhārī, Șaḥị̣ al-Bukhān̄̄, Jilid 6, h. 147 dan Abū al-Ḥusain Muslim bin al-Ḥajjāj al-Qusyairī al-Naisābūrī, Șậh Muslim, Jilid 3, h. 1678.

${ }^{39}$ Abū Zakariyyā Yahyā bin Syarf al-Nawawī, al-Minhāj Syaṛ̣u Șaḥị̣ Muslim bin al-Hajjāj, Jilid 14 (cet. 2, Beirut: Dār Ihyā'u al-Turāś al-‘Arabī, 1392 H/1972 M), h. 106.

${ }^{40}$ Abdurraḥmān bin Nāșir bin Abdullāh al-Sa'dī, Taisìr al-Kan̄m al-Raḥmān fi Tafsìr Kalām alMannān, h. 203. 
untuk dikebiri, membuat tato dan apa-apa yang dilarang untuk ditato serta bentukbentuk kemaksiatan lainnya. ${ }^{41}$

Pendapat ini berdasarkan firman Allah Allah swt. dalam Q.S. al-Rūm/30: 30:

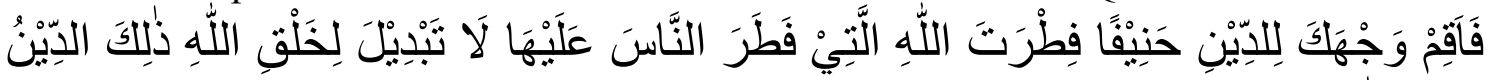

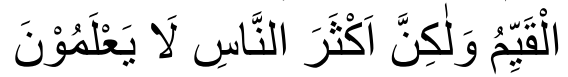

Terjemahnya:

Maka hadapkanlah wajahmu dengan lurus kepada agama (Islam); (sesuai) fitrah Allah disebabkan Dia telah menciptakan manusia menurut (fitrah) itu. Tidak ada perubahan pada ciptaan Allah. (Itulah) agama yang lurus, tetapi kebanyakan manusia tidak mengetahui. ${ }^{42}$

Hal ini dikuatkan dengan hadis Abū Hurairah bahwa Rasulullah saw. bersabda:

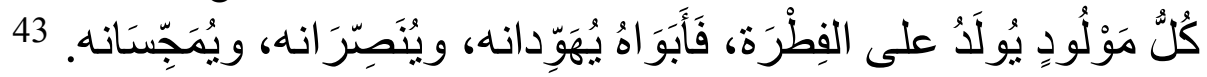

Artinya:

Setiap anak dilahirkan atas fitrah, maka hanya kedua orang tuanyalah yang menjadikannya seorang Yahudi, atau seorang Nasrani, atau seorang Majusi.

Mengenai makna mengubah ciptaan Allah dalam hal mengubah fitrah keagamaan, al-Qurțubī mengemukakan tentang ciptaan Allah (makhluk-Nya) yang disalahgunakan, yang seharusnya binatang diciptakan sebagai tunggangan dan dagingnya sebagai makanan, serta menciptakan matahari, bebatuan dan berbagai sesuatu untuk dijadikan sebagai iktibar dan didayagunakan kemanfaatannya. Akan tetapi semuanya itu diubah menjadi ilah yang disembah dan hal itu merupakan perbuatanperbuatan yang menjadikan sekutu bagi Allah dan menyalahi perintah untuk bertauhid, yang kesemuanya itu mengajak kepada neraka dan akan menghancurkan akidah. Semua itu terjadi karena tindakan dan usaha setan untuk memalingkan manusia dari jalan yang benar menuju jalan yang sesat, sehingga mereka tersesat dan menempuh jalan yang diinginkan setan.

Pendapat ini didukung oleh al-Sa'dī. Beliau menjelaskan bahwa Allah swt. menciptakan makhluk dalam keadaan suci dan bernaluri untuk menerima kebenaran dan mendahulukannya, kemudian hadirlah setan kepada mereka lalu menggoda mereka untuk mengubah penciptaan yang indah itu. ${ }^{44}$

${ }^{41}$ Abu Ja'far Muhammad bin Jarīr al-Ṭabarī, Jamī' al-Bayān fi Ta’w̄̄l al-Qur'ān, Jilid 9, h. 222.

${ }^{42}$ Kementrian Agama RI, Al-Qur'an dan Terjemahnya, h. 407.

${ }^{43}$ Abū 'Abdillāh Muhammad bin Ismā‘̄il bin Ibrāhīm bin al-Mugīrah bin Bardizbah al-Ju'fī alBukhārī, Șạ̣ị̣ al-Bukhān̄̄, Jilid 2, h. 100 dan Abū al-Ḥusain Muslim bin al-Ḥajjāj al-Qusyairī al-Naisābūrī, Șahị Muslim, Jilid 4, h. 2047.

44، Abdurraḥmān bin Nāṣir bin 'Abdullāh al-Sa' dī, Taisīr al-Kan̄m al-Raḥmān fi Tafsīr Kalām alMannān (Beirut: Mu’assasah al-Risālah, 1420 H/2000 M), h. 203. 
Disebutkan dalam hadis yang diriwayatkan oleh 'Iyaụ bin Ḥimār, Rasulullah saw. bersabda, Allah swt. berfirman:

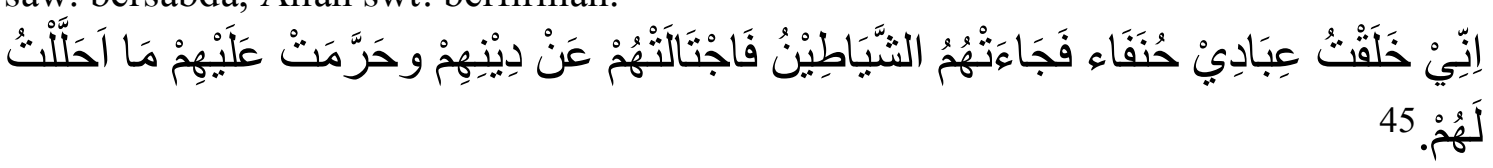

Artinya:

Sesungguhnya Aku telah menciptakan hamba-hamba-Ku cenderung kepada agama-Ku, maka datanglah setan kepada mereka, lalu setan itu memalingkan mereka dari agamanya dan ia mengharamkan apa yang telah Aku halalkan bagi mereka.

Pendapat ini juga didukung oleh Ibnu Kasiīr yang mengutip pendapat dari para ulama. Disebutkan dalam kitabnya, Tafsīr al-Qur'ān al-'Aẓ̂̀m, bahwa maksud dari khalqallāh dalam ayat ini menurut Ibnu 'Abbās, Mujāhid, 'Ikrimah, Ibrāhim al-Nakhā'ī, al-Hasan, Qatādah, al-Ḥakam, al-Saddī, al-Dahhak, dan Ata al-Khurasanī adalah agama Allah swt. ${ }^{46}$ Ayat ini berdasarkan tafsir tersebut semakna dengan firman Allah swt. dalam Q.S. al-Rūm/30: 30:

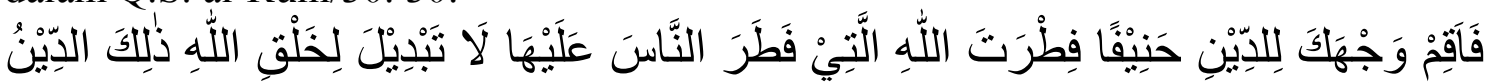

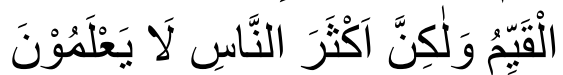

Terjemahnya:

Maka hadapkanlah wajahmu dengan lurus kepada agama (Islam); (sesuai) fitrah Allah disebabkan Dia telah menciptakan manusia menurut (fitrah) itu. Tidak ada perubahan pada ciptaan Allah. (Itulah) agama yang lurus, tetapi kebanyakan manusia tidak mengetahui. ${ }^{47}$

Menurut penafsiran orang yang menjadikan masdar sebagai kata perintah, artinya adalah 'janganlah kalian mengganti fitrah Allah, dan serulah manusia untuk kembali kepada fitrah mereka', seperti yang disebutkan di dalam sebuah hadis bahwa Rasulullah saw. bersabda:

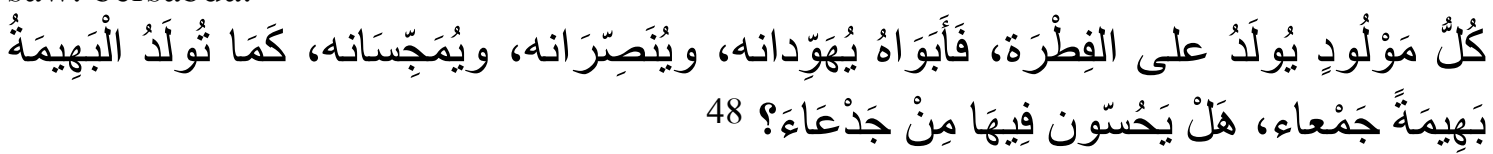

Artinya:

Setiap anak dilahirkan atas fitrah, maka hanya kedua orang tuanyalah yang menjadikannya seorang Yahudi, atau seorang Nasrani, atau seorang Majusi.

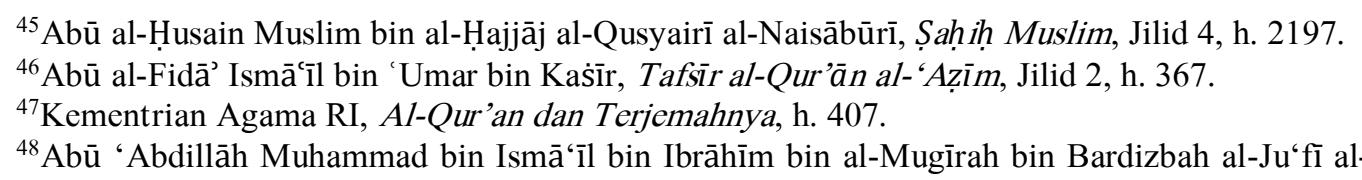
Bukhārī, Sahịh al-Bukhān̄̄, Jilid 2, h. 100 dan Abū al-Husain Muslim bin al-Hajjāj al-Qusyairī alNaisābūrī, Șậ ị̣ Muslim, Jilid 4, h. 2047. 
Sebagaimana binatang ternak melahirkan binatang ternak yang utuh, maka apakah kalian menjumpai padanya anggota tubuhnya yang tidak lengkap?

Wahbah al-Zuhailī juga menambahkan pengubahan ciptaan Allah dalam fitrah keagamaan termasuk pengubahan ciptaan Allah yang dilarang agama, karena itu termasuk perintah setan kepada manusia untuk mengubah fitrah keagamaan yang telah ditetapkan untuk mereka, baik secara material maupun secara nilai, sehingga manusia terjatuh dalam kejahatan, sebagaimana perkataannya:

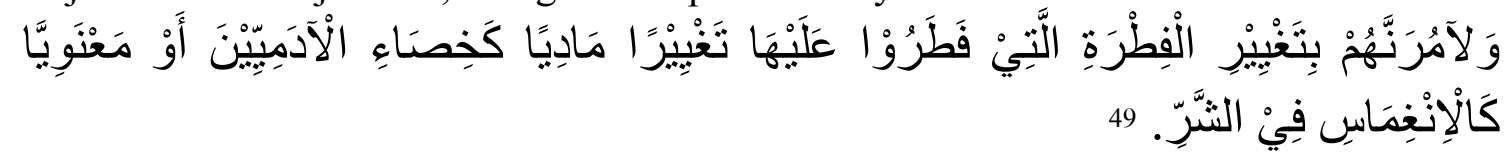

Artinya:

Kami (setan) akan memerintahkan mereka (manusia) untuk mengubah fitrah yang telah ditetapkan untuk mereka, baik secara material, yaitu mengebiri manusia maupun secara nilai, yaitu tenggelam dalam kejahatan.

Menurut Jamāluddīn al-Qāsimī, "ciptaan Allah" yang dimaksud adalah agama Allah sebagaimana penafsiran sahabat Ibnu "Abbās dan banyak ahli tafsir. Beliau mengatakan:

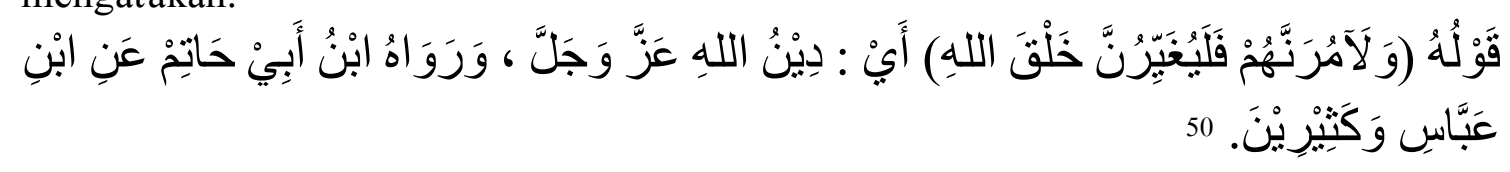

Artinya:

Aku (setan) akan memerintahkan mereka (manusia) untuk mengubah ciptaan Allah, maksudnya agama Allah sebagaimana riwayat Ibnu Abī Ḥātim dan Ibnu 'Abbās dan banyak ahli tafsir.

Dari beberapa pendapat para ulama dalam masalah mengubah ciptaan Allah yang tercantum dalam Q.S. al-Nisā'/4: 119, maka maksud dari Tagyīr Khalqillāh ( تغيير adalah sebagai berikut: a) mengebiri manusia dan binatang, b) mengubah bentuk fisik, c) membuat tato di tubuh, d) mengubah agama Allah.

\section{Hukum Penggunaan Aplikasi FaceApp Melalui Kamera}

Aplikasi FaceApp telah beredar di kalangan masyarakat, sehingga sebagian orang mulai mempertanyakan tentang hukum menggunakan aplikasi ini. Melihat fenomena seperti ini, para ulama pun berusaha untuk menentukan hukumnya dengan menggunakan dalil-dalil yang ada dan pemikiran mereka, sehingga ada perbedaan pendapat di antara mereka terkait masalah penggunaan aplikasi ini. Ada di antara mereka yang mengharamkannya dan ada juga yang membolehkannya.

\footnotetext{
${ }^{49}$ Wahbah al-Zuhailī, al-Tafsīrul al-Waj̄z, h. 98

${ }^{50}$ Jamāluddīn al-Qāsimī, Maḥāsin al-Ta’w̄̄l, Jilid 5, h. 1568.
} 
Di antara ulama yang mengharamkan penggunaan aplikasi semacam ini adalah Abdurraḥmān al-Suhaim. ${ }^{51}$ Beliau mengatakan:

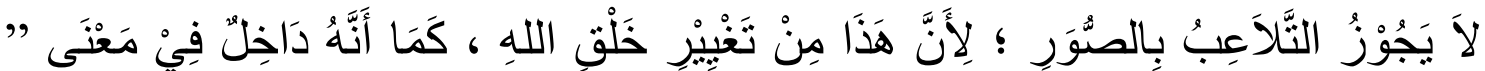

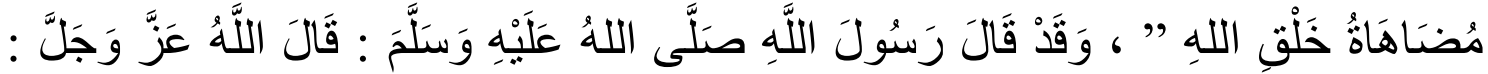

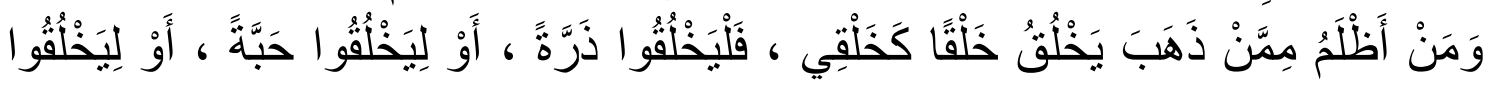

Artinya:

Tidak boleh main-main dengan gambar (makhluk bernyawa). Karena ini termasuk menandingi ciptaan Allah. Sebagaimana itu masih termasuk dalam cakupan 'menandingi ciptaan Allah'. Dan Rasulullah saw. bersabda: Allah swt. berfirman: siapa yang lebih zalim dari orang yang menciptakan seperti ciptaan$\mathrm{Ku}$ ? (Siapa yang mau membuat gambar) maka buatlah gambar benih, biji, atau gandum.

Termasuk di dalam pendapat ini adalah mengedit foto dengan menggunakan aplikasi FaceApp.

Pendapat lainnya juga meyebutkan ada beberapa pelanggaran syariat yang dilakukan oleh pengguna aplikasi ini, di antaranya:

1. Dia secara tidak langsung melakukan perbuat an syirik ketika dia meyakini bahwa kelak wajahnya akan seperti itu saat dia memasuki usia tua. Aplikasi ini seolaholah meramal masa depan dan meramal masalah gaib, seperti dukun dan tukang ramal. Dengan kata lain, aplikasi ini seolah-olah meramal bentuk wajah penggunanya ketika dia tua nanti, sehingga pengguna tersebut percaya bahwa dia akan tua seperti itu. Sama halnya seperti dia mendatangi dukun dan tukang ramal, kemudian dia berkonsultasi dengannya dan mempercayai apa yang dikatakan oleh dukun dan tukang ramal tersebut.

2. Jika dia menggunakannya untuk main-main saja, maka dia terjatuh ke dalam syirik kecil.

3. Dia telah mendahului takdir, karena dia telah mendahului Allah swt. dalam menentukan bentuk wajahnya ketika dia tua nanti.

4. Dia telah mengubah ciptaan Allah. Walaupun yang diubah itu hanya berbentuk foto atau gambar, tapi dia seolah-olah merubah ciptaan Allah dalam gambar tersebut dengan menggunakan aplikasi ini, baik itu dia mengubahnya menjadi lebih muda, lebih tua, atau mengubah gender.

${ }^{51}$ Lihat: https://www.djelfa.info/vb/archive/index.php/t-1448845.html (diakses pada tanggal 10 Agustus 2020).

${ }^{52}$ Abū al-Ḥusain Muslim bin al-Ḥajjāj al-Qusyairī al-Naisābūrī, Șaḥị̣ Muslim, Jilid 3, h. 1671. 
5. Dia telah menggambar dan membuat serta mengubah gambar yang bernyawa dengan tangannya sendiri, seperti membuat dan mengubahnya menjadi lebih muda, lebih tua, atau mengubah gender. ${ }^{53}$

Namun ada beberapa ulama kontemporer yang membolehkan penggunaan aplikasi FaceApp, karena menurut mereka, di dalamnya tidak ada unsur menciptakan sesuatu dengan menyerupai makhluk Allah, sedangkan tașwìr yang dimaksud di atas semisal melukis kuda atau patung dengan tangan. Hal itu dapat dikategorikan lukisan yang menyerupai ciptaan makhluk Allah.

Selain itu, aplikasi FaceApp menggunakan gambar yang dihasilkan dari fotografi, sedangkan fotografi tidak termasuk kategori taș wīr (lukisan) yang dilarang oleh Rasulullah, karena gambar yang dihasilkan dari fotografi bukan seperti lukisan yang dibuat dengan tangan, tapi fotografi mengambil gambar dengan cara penangkapan bayangan dengan alat yang modern. Hal ini diperkuat dengan adanya sebutan masyarakat Kuwait untuk gambar fotografi: 'aks (pantulan), dan fotografernya: 'ākas (pemantul). ${ }^{54}$

\section{KESIMPULAN}

Berdasarkan pemaparan di atas, dapat disimpulkan bahwa:

Pertama, FaceApp adalah aplikasi yang dapat mengubah foto wajah menjadi lebih muda, lebih tua, atau mengubah gender. Untuk bisa melakukan hal tersebut, FaceApp menggunakan teknologi berupa jaringan saraf yang secara otomatis menghasilkan transformasi wajah yang sangat realistis dalam foto. Pendapat para ulama dalam masalah mengubah ciptaan Allah yang tercantum dalam Q.S. al-Nisā'/4: 119 memiliki maksud sebagai berikut: a) mengebiri manusia dan binatang, b) mengubah bentuk fisik, c) membuat tato di tubuh, d) mengubah agama Allah.

Kedua, hukum penggunaan aplikasi FaceApp dalam perspektif Islam oleh para ulama terbagi menjadi dua: sebagian ulama mengharamkan penggunaan aplikasi FaceApp dan sebagian lainnya membolehkannya. Namun demikian, mayoritas ulama

\footnotetext{
${ }^{53}$ Lihat: Isham Ar Rubi, https://mashranews.com/post/144369/, Ahmad Madkur, http://ababeel.news/9113--faceapp.html, Usman dan al-Khamis, https://www.youtube.com/watch?v=DvgZJTcZqTk. (10 Agustus 2020)

${ }^{54}$ Lihat: Ahmad al-Maliki, https://www.falsoo.com/news/2/26168/\%D9\%87\%D9\%84\%D8\%A7\%D8\%B3\%D8\%AA\%D8\%AE\%D8\%AF\%D8\%A7\%D9\%85\%D8\%AA\%D8\%B7\%D8\%A8\%D9\%8A\%D9\%82-faceapp-\%D8\%AD\%D8\%B1\%D8\%A7\%D9\%85\%D8\%B4\%D8\%B1\%D8\%B9\%D9\%8B\%D8\%A7-\%D8\%A7\%D9\%84\%D8\%B4\%D9\%8A\%D8\%AE\%D8\%A3\%D8\%AD\%D9\%85\%D8\%AF-\%D8\%A7\%D9\%84\%D9\%85\%D8\%A7\%D9\%84\%D9\%83\%D9\%89\%D9\%8A\%D8\%B1\%D8\%AF (diakses tanggal 11 Agustus 2020) dan Said Agil Husin Munawwar dan Abdul Mustaqim, Asbabul Wurud; Studi Kritis Hadis Nabi, Pendekatan Sosio-Historis-Kontekstual. (Yogyakarta: Pustaka Pelajar Offset, 2001), h. 105.
} 
kontemporer memilih untuk mengharamkannya, berdasarkan dalil-dalil dalam AlQur'an dan hadis yang terkait serta banyaknya pelanggaran dan mudarat yang ditimbulkan oleh aplikasi ini. Dalam hal ini, mencukupkan diri dengan sekadar memotret wajah untuk kebutuhan identitas, pengenalan atau hal lainnya yang dipandang maslahat adalah tetap diperbolehkan selama tidak ada upaya mengubah gambar dari bentuk aslinya, dan hal ini merupakan bentuk kehatian-hatian yang lebih baik. Wallahu a'lam.

\section{DAFTAR PUSTAKA}

'Abdurrahmān bin 'Abdul Khāliq. (1994). Ahkōmu al-Taṣwir fi al-Syañ’ah alIslämiyyah.

Abū al-Fidā' Ismāēil bin 'Umar bin Kas̀īr. (1999). Tafsìr al-Qur'ān al- 'Aẓīm, Jilid 2 dan 5. Cet. I; Beirut: Dār al-Kutub al-'Ilmiyyah.

Abū Bakr 'Abdullāh bin Muhammad bin Ibrāhīm bin Abī Syaibah. (1425 H/ 2004 M). Al-Muṣnaf li ibn Abī Syaibah, Jilid 12. Cet. I; Riyaḍ: Maktabah al-Rusyd Nāsyirūn.

Al-'Uṡaimīn, Muhammad bin Șālih. (1994). Al-Qaul al-Mufid 'alā Kitā b al-Tauḥìd, Jilid 2 Cet. I, Beirut: Dār al-'Āṣimah.

Al-Asqalānī, Ibnu Hajar. (2005). Fatḥ u al-Bānn̄ bi Syaṛ̣ Șaḥ ị̣ al-Bukhānī, Jilid 6. Riyaḍ: Dār al-Tîbā'ah.

Al-Bajādī, 'Abdul 'Azīz bin Aḥmad. (2003). Mas'alatu al-Taș wīr Mustallatun min al'Imād fi Syarhi al-Zād.

Al-Bukhārī, Abū 'Abdillāh Muhammad bin Ismā'īl bin Ibrāhīm bin al-Mugīrah bin Bardizbah al-Ju'fī. (2002). Șạh ị̣ al-Bukhānī, Jilid 2. Cet. I; Beirut: Dār Ṭūq alNajāh.

Al-Khattāāì Abū Sulaimān hamd bin Muhammad bin Ibrāhīm bin al-Khatțāb. (1932). Ma'ālim al-Sunan, Jilid 3 .Cet. I; Aleppo: al-Mațba'ah al-'Ilmiyyah.

Al-Qāsimī, Jamāluddīn. (1996). Maḥ̄̄sin al-Ta’mīl, Jilid 5. Cet. I; Damaskus: Dār alFikr.

Al-Qurțubī, Abū 'Abdullāh Muhammad bin Ahmad bin Abu Bakr al-Anșarī. (1964). AlJāmi' li Ahkām al-Qur'ān, Jilid 5. Cet. II; Kairo: Dār al-Kutub al-Mișriyyah.

Al-Qurțubī, Abū 'Umar Yūsuf bin Abdillah bin Muhammad bin Abdil Barr bin 'Āșim al-Namarī. (2000). Al-Istiž kār, Jilid 8. Cet. I; Beirut: Dār al-Kutub al-'Ilmiyyah/

Al-Sa'dī, 'Abdurraḥmān bin Nāṣir bin 'Abdullāh. (2000). Taisīr al-Karīm al-Raḥmān fi Tafsìr Kalām al-Mannān. Beirut: Mu’assasah al-Risālah.

Al-Sajastanī, Abū Dāwud Sulaimān bin al-Asy'as̉ bin Isḥāq bin Basyīr al-Azdī. (1997). Sunan $A b \bar{l}$ Dā wud, Jilid 4. Cet. I; Beirut: Dār Ibnu Ḥazm.

Al-Ṭabarī, Abu Ja'far Muhammad bin Jarīr. (2000). Jamī' al-Bayān fi Ta'wīl al-Qur'ān, Jilid 9. Beirut: Mu'assasah al-Risālah.

Ḥamūd bin 'Abdillāh al-Tuwaijirī. (1988). Taḥn̄m al-Taṣwìr wa al-Radd 'alā Man Abāhahu. 
BUSTANUL FUQAHA: Jurnal Bidang Hukum Islam

Vol. 1, No. 3 (2020) : Hal. 484-504

Website: https://journal.stiba.ac.id

Imamah, Naili. (2019). Relevansi Hadis tentang Larangan Menggambar Makhluk Bernyawa di Masa Sekarang (Studi Ma'anil Hadis). (Skripsi). Surakarta: Fak. Ushuluddin dan Dakwah Institut Agama Islam Negeri.

Najichah, Iffa Yuliani Ainun.(2016). Pemahaman Hadis tentang Gambar (Analisis Makna صورة dalam Hadis). (Skripsi). Semarang: Fak. Ushuluddin dan Humaniora UIN Walisongo.

Suryadilaga, Alfatih (2012). Metodologi Syarah Hadis. Yogyakarta: SUKA-Press. 